Urban Studies, Vol. 40, No. 3, 615-630, 2003

\title{
'Making Friends or Making Things?': Interfirm Transactions in the Sheffield Metal-working Cluster
}

\author{
H. D. Watts, A. M. Wood and P. Wardle \\ [Paper first received, April 2002; in final form, July 2002]
}

Summary. The paper comprises an examination of the material inputs of a sample of 70 small firms in the Sheffield metal-working cluster and an assessment of the extent to which purchases are accompanied by face-to-face (embodied) transactions. It is shown that there are no significant differences between the level of embodied transactions accompanying local (intracluster) material links and those associated with non-local flows. It seems that, on this measure at least and within this cluster, the Sheffield metal-working cluster lacks the dense network of embodied transactions with local suppliers suggested in the wider literature. The lower-thanexpected measures of embodied transactions suggest that one of the mechanisms for the transfer of knowledge between buyers and suppliers within an industrial cluster is poorly developed in this particular case.

\section{Introduction}

Geographical clusters of economic activity (sometimes described as industrial districts or industrial agglomerations) are currently centre-stage in the research (for example, Gordon and McCann, 2000; Kaufmann and Todtling, 2000) and policy agenda (Porter, 2000; den Hertog et al., 2001; Department of Trade and Industry, 2001) of those concerned with urban and regional development. Clusters are seen to have a number of benefits both to the individual firm and to the locality or region as a whole. Furthermore, clustering is thought to encourage activities to 'stick' to particular places (Markusen, 1996). In policy terms, areas with clusters of related firms are seen to be successful and therefore worth replicating.

Geographical clusters are recognised at a variety of geographical scales. They have been identified at the national scale (Porter, 1998), the regional scale (such as motor sport valley in the UK, see Pinch and Henry, 1999), the urban scale (usually focused on a single city; see, for example, Pyke et al., 1990; Pyke and Sengenberger, 1992) and, indeed, as clusters within cities such as those described by Scott (1988) in Los Angeles. The latter are similar, at least in certain respects, to the industrial quarters identified over half a century ago in London and 
Birmingham (Wise, 1949; Hall, 1960). Just as there are variations in the geographical scale at which clusters are identified, it is also possible to draw a broad distinction between high-technology clusters (Garnsey and Lawton-Smith, 1998; Keeble and Wilkinson, 1999) and more traditional clusters based on older and well established industries (Applold, 1995; Boschma and Lambooy, 1999). The focus of this paper is on clusters of traditional economic activity within urban regions. Its specific contribution is to document and report the extent of embodied transactions (i.e. face-to-face meetings) between owner-managers of small firms and their suppliers within the traditional industries of the Sheffield metalworking cluster.

The paper is in five parts. It begins with a discussion of the nature of interfirm relationships within traditional industrial clusters. The methodology of the study is then outlined and this is followed by a discussion of the nature of the cluster in which the investigation was undertaken. The fourth section of the paper examines the links between small firms and their suppliers measuring the extent to which commodity flows are accompanied by embodied transactions whilst the fifth section focuses on the geographies of these transactions. A sixth and final section argues that the findings tend to challenge an orthodox view that clusters are associated with networks of dense social interaction between owner-managers linked through commodity flows.

\section{Small Firm Clusters}

The organisational forms of spatial clusters may vary (Markusen, 1996), but the interest here is in clustered manufacturing activities whose business structures are dominated by small locally owned firms. Although some spatial clusters of small firms might simply reflect co-location around a particular resource or market, it is often argued that small firms from related sectors are predisposed to benefit from clustering together in a specific location. These benefits are associated with traditional agglomeration (external) economies or, more specifically, the subset of activities known as localisation economies. More recent work draws on Granovetter's notion that economic activity is embedded within broader sets of social relations (Granovetter, 1985). Accordingly it makes much of the benefits that accrue from face-to-face or embodied transactions between economic agents. These transactions are seen to facilitate information exchange that in turn promotes cluster 'learning' such that the competitive advantages of individual firms within the cluster are enhanced over those outside. Other things being equal, small firms in a cluster are expected to display higher levels of innovation, generate better returns and have longer survival times than their geographically isolated counterparts. Since firms in clusters are deemed for these reasons to be more successful than equivalents beyond them, it is a short step to the expectation that urban regions with clusters of related activities will perform better than those without.

Yet evidence is beginning to mount that the 'success' attributed to clusters and their constituent firms may not be as widespread as first thought. Staber (2001), for example, demonstrates the lower survival rates of small firms in clusters compared with those outside them, whilst Oakey et al.'s (2001) recent study of high-technology clusters in the South East of England finds that the extent of a firm's intracluster links is inversely related to various indicators of management sophistication. Similarly, the recognition of what has been termed 'political lock-in' stresses that rigidity rather than flexibility may be a characteristic of wellestablished clusters (Grabher, 1993a; Hassink, 1997). The significance of social networks to cluster performance has also been challenged. For example, in a study of innovation in five European city-regions, Simmie et al. (2002, p. 54) note that "social networks... [such as presence of excolleagues and friends]... were usually scored low in importance to innovations by firms". The emergence of these qualifications 
on the one hand, and the widening application of cluster policies on the other, suggests that the present time is an opportune one to look closely at the characteristics of clusters. In particular, it seems important to attempt to unpack and empirically document the processes that are thought to drive cluster development and success.

The advantages that accrue to firms within a cluster can be reduced to three broad groups. First, there are the advantages of vertical integration with suppliers and customers in close proximity. Secondly, there are the advantages of horizontal integration such as the exchange of information about markets and technical change as well as access to specialised skills within the local labour market. Finally, there are the advantages of institutional support, from local government organisations, venture capital funds and research units such as universities, training providers and the like. In each case proximity is assumed to confer advantages to the firm.

This paper focuses specifically on vertical linkages between firms and more particularly on input (backward) linkages from suppliers rather than output (forward) linkages to customers. It is argued below that the cluster literature typically suggests that withincluster exchanges between buyers and suppliers are frequent and significant and that these exchanges within the commodity chain are associated with a high frequency of embodied transactions between trading partners.

The importance of these transactions within clusters has been especially emphasised in contemporary analyses of hightechnology clusters. Work rooted in concepts of the local milieu, untraded interdependencies and collective learning, all hint at the importance of face-to-face meetings between entrepreneurs in facilitating linkages, developing trust and generating localised norms and routines. For example, Gertler's work on the adoption of advanced manufacturing technologies points to the importance of geographical proximity in facilitating highquality or "interaction-intensive" relationships between users and producers: "site visits were absolutely crucial for ultimate success when the technology being implemented was new, complex, and expensive" (Gertler, 1995, p. 16; emphasis added). This is especially true of the smaller firms in Gertler's sample.

While the importance of face-to-face contacts is emphasised in analyses of hightechnology clusters, embodied transactions are also central to analyses of clusters based on traditional industries. Camagni's classic account of collective learning emphasises the

presence of an intricate network of mainly informal contacts among local actors, building what Marshall called an 'industrial atmosphere', made up of personal face-to-face encounters, casual information flows, customer-supplier cooperation and the like (Camagni, 1991, p. 133; emphasis added).

Similarly, in an examination of the Italian model of spatial development, Garolfini argues that

face-to-face relations between actors [especially the suppliers and users of intermediate goods ...] favour a cascade effect in the transmission of technological and organisational improvement through the system of firms (Garolfini, 1991, pp. 9596).

More recently, Amin has stressed how, within clusters of traditional industries,

economic interdependency, social familiarity, and face-to-face contact ... helped firms to reduce the cost of their transactions ... [and] ... facilitate the flow of information and knowledge (Amin, 2000, p. 153).

In sum, MacKinnon et al.'s review of recent literature argues that an

emphasis on tacit knowledge makes spatial proximity between associated producers more important since this form of noncodified knowledge is best transmitted and developed through close inter-personal and inter-firm relations (MacKinnon et al., 2002, p. 301; emphasis added). 
Such arguments generate two questions that would seem to repay further study.

(1) To what extent is commodity exchange accompanied by embodied transactions between trading partners?

(2) To what extent are these embodied transactions more prevalent within clusters than beyond them?

A key feature of this study is its comparative assessment of the characteristics of localised and non-localised exchange. This allows the development of a clear indication of the extent to which intracluster exchanges between firms differ from extracluster exchange. An initial assessment can therefore be made of some of the distinctive features of withincluster exchange relationships.

Inevitably, exploring the detailed workings of a cluster forces us to focus on certain selected aspects of cluster activities. Attention has already been drawn to the focus on traditional industries, on vertical linkages and, in particular, on vertical input linkages. Input linkages between firms can take a number of forms and a general distinction can be drawn between material linkages or those involving tangible commodities and service linkages. Material linkages usually refer to the flows of material inputs and outputs between plants (the precise definition used in this study is given below), while service linkages are the inputs received from service providers (such as financial institutions and cleaning contractors). This paper focuses on material linkages for two reasons. First, these are typically four to five times more important than service inputs in terms of value (PA Cambridge Economic Consultants, 1995, p. 153); and, secondly, and more especially given the study context, material commodity flows are readily distinguishable from embodied transactions between trading partners. Clearly, service linkages are more prone to embodied forms of exchange in which the social and economic aspects of interaction tend to be conflated. This is particularly true of high-value services such as management consultancy and financial services. The distinction between embodied transactions and the exchange of material commodities is a much clearer one.

\section{Methodology}

The research is focused upon a group of firms that fall within Division Three 'Metal goods, engineering and vehicle industries' of the 1980 UK SIC. These are referred to for the remainder of the paper as 'metal-working firms' and a more detailed description of their specific activities is provided in the section that follows. In general, metalworking firms have a more extensive and varied range of linkages than many other sectors (Grotz and Braun, 1993; Perry and Goldfinch, 1996). It has also been argued that the sector is characterised by firms interacting through the establishment of trust and co-operation rather that atomised competition (Lorenz, 1988). On this basis, high levels of commodity exchange and embodied transactions might be expected to characterise the metal-working cluster.

The linkages of a sample of metal-working firms are explored within a city-region. As Camagni notes

cities are milieux with some special characteristics. Like all milieux, they contain the elements of proximity, strong internal integration, synergy, and psychological and cultural identity (Camagni, 1995, p. 198).

Sheffield, the study site, is popularly recognised as a centre of metals and metal goods manufacture both historically (Marshall, 1919) and presently (Department of Trade and Industry, 2001). The strength of this association derives from 700 years of metals and metal-working within Sheffield and its immediate surroundings (Tweedale, 1996; Binfield and Hey, 1997). This association between Sheffield and its metal-working traditions is repeatedly reinforced via the popular media most recently through the film 'The Full Monty'. The metal-working industry is geographically clustered within an urban region of $10-15 \mathrm{~km}$ in diameter. While other 'clusters', such as the UK's motor sport 
valley (Pinch and Henry, 1999), cover very much larger geographical areas and encompass multiple urban centres, the geographical extent and single-city focus of the Sheffield case resonate with the classic individual industrial districts of the Third Italy (Pyke et al., 1990; Pyke and Sengenberger, 1992).

In studying small firms in the metalworking sector, we can assume a relatively direct link between characteristics of the firm and its owner-manager and linkage patterns. In these small independent firms, ownermanagers' actions are not constrained or influenced by parental organisations. Similarly, in the smaller firm, owner-managers tend to be involved directly in negotiations with suppliers rather than employing specialised buyers to source inputs. The definition of a small firm used here is: "the revised European Union definition ... [which] ... defines a small firm as one with under 50 employees" (Department of Trade and Industry, 1999, p. 128).

The sample was drawn from a list of 243 small firms in the metal-working sector in the Dun and Bradstreet data-base. Although comparison with ONS data on small plants in Sheffield suggests that this was an underestimate (particularly of the firms with less than 10 employees) the Dun and Bradstreet data provide the most comprehensive list available. The data were cleaned (removing small firms which were defunct or subsidiaries of other organisations), reducing the sample frame to 214 firms. Having identified an appropriate sample size (reflecting the planned mode of analysis as well as the time available for field work) a random sample was drawn and 70 owner-managers agreed to a face-to-face interview using a semistructured interview schedule. These firms represent a response rate of 75 per cent. Tests for response bias were possible on sector and size and no significant difference was found between the respondents and the original population.

In order to assess the extent and nature of interfirm linkages, attention was focused on links with the principal supplier of the firm's main input by value. In this way, we can examine directly the extent of embodied transactions associated with a specific exchange relationship comparable across the sample of firms. A working definition of 'the local' (i.e. a 'local' as recognised by the respondents) proved problematic in a pilot survey: although the firms were sampled within the city of Sheffield, local suppliers were defined as those within South Yorkshire and north-east Derbyshire, an area extending to $30 \mathrm{~km}$ or so from the city itself (Figure 1). The tightly drawn boundary immediately to the west of the cluster reflects the virtual absence of potential suppliers in the Peak District National Park separating Sheffield from Manchester.

Embodied transactions were measured by asking respondents to estimate the number of face-to-face meetings with a principal contact at the supplier firm over the past year. We cannot verify the accuracy of such estimates, but it is worth noting that respondents had little difficulty in providing a ready response. Respondents were also asked to distinguish between meetings on business premises (usually the suppliers' or buyers' business premises), meetings on nonbusiness premises to discuss principally business matters (such as lunch meetings to discuss order or product specifications) and meetings beyond the firm with no specific business agenda (such as at a sports or social club or charitable event). Principal suppliers included local and non-local firms, but the expectation from the cluster literature was that embodied transactions would usually accompany links with local suppliers but would be much less likely to accompany transactions with non-local suppliers.

To summarise, the data on which this paper is based were collected through faceto-face interviews with the owner-managers of 70 small metal-working firms with less than 50 employees located in the city of Sheffield. Whilst the analysis is based on descriptive summary statistics such as the mean and the median, the association between variables is assessed through the cross-tabulation of bivariate relationships 


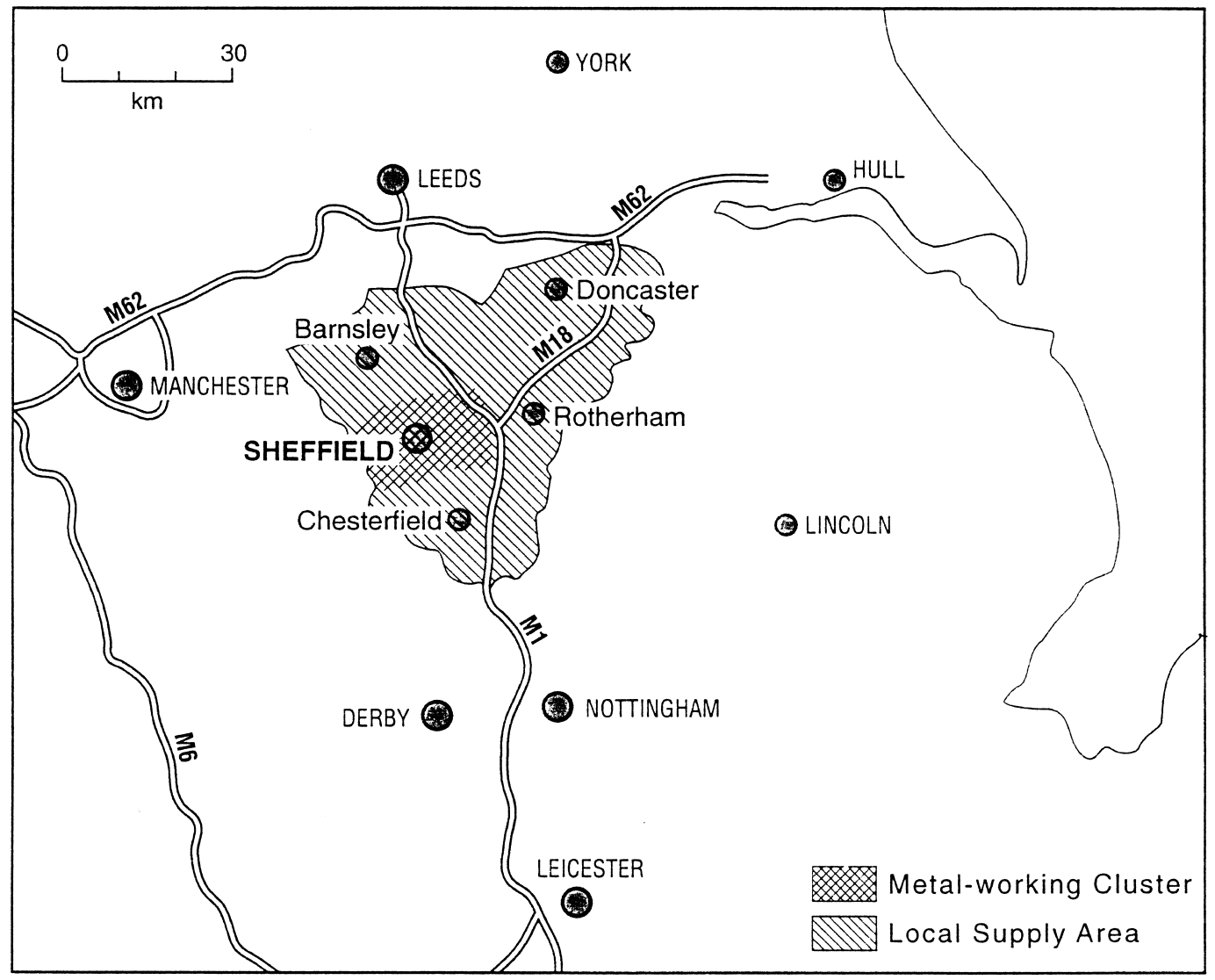

Figure 1. The location of the Sheffield metal-working cluster.

using dichotomous variables where $\mathrm{p}<0.05$ is taken as the minimum level of statistical significance. The direction of determination of linkage patterns is uncertain in the majority of cases. For this reason, two-tailed tests are used throughout the analysis. Reference is made to interrelationships between independent variables and there are comments on these where appropriate, but no formal testing of multivariate relationships is undertaken. In part, this is through caution concerning the precise nature of any explanatory capacity given the sample size and ambiguity in the literature concerning the direction of any determinant relationships.

\section{The Sheffield Metal-working Cluster}

Sheffield, a city of around half a million people, has a metal-working sector employ- ing over 25000 - just under two-thirds of the city's entire manufacturing workforce. Although Sheffield's manufacturing employment fell from around 120000 employees in 1978 to around 40000 some 20 years later, Sheffield is still a city in which manufacturing as a whole and metal-working in particular are of major importance. Thus, while employment in the metal-working industries fell dramatically after 1979, a commentator observed that "in the 1980s Sheffield was making more steel than it had in the Second World War and early 1950s" (Tweedale, 1996, p. 392). Although the engineering and vehicles sectors are underrepresented in the city, the proportion of employment in metal products is three times the national average.

Within this cluster, the small firm has always been an important component of the Sheffield economy. Huge plants, commonly 
part of large multilocational firms, co-existed with clusters of small metal-working factories scattered around the city in a successful 'dual economy'. However, contraction of employment in the larger plants has increased the employment significance of the smaller plants and firms. Amongst manufacturing plants of less than 50 employees, over two-thirds are in the metal-working sector. Whilst recognising the important distinction between small plants and small firms, there seems little doubt as to the importance of small firms in the Sheffield metal-working cluster. Aggregate data in the public domain provide little further information about the nature of the metal-working cluster and the remainder of this paper is drawn from the survey of the 70 small firms.

Reference has already been made to the long history of the Sheffield metal-working cluster but, although one firm claimed 18thcentury origins, very few could trace their foundation back beyond 1950. Indeed, threequarters had been founded in the second half of the 20th century, including a third within the past 30 years. Some firms were in modern premises, but others, particularly the smallest, tended to occupy marginal or rundown properties. The activities of the firms fell into two broad groups (Table 1). Firms in the first group manufacture particular products such as castings, forgings, fastenings, cutting tools, hand saws and springs, whilst those in the second group undertake metal treatments of various kinds such as electroplating, grinding, heat treatment and shot blasting. The essentially traditional nature of the industry is seen in the fact that only a quarter of the firms described their process as a high-tech one and more significantly only just over a tenth defined their products as high-technology products. Overall, the majority of firms (72 per cent) were selling to intermediate markets.

As expected, most ( 85 per cent) of the small firms were run by owner-managers. The exception were those run by full-time managers working for retired owners who had relinquished overall day-to-day control of the firm but continued to maintain a financial stake. Since these managers maintained day-to-day control with little interference on the part of the proprietor, they too were regarded as owner-managers for analytical purposes. It came as no surprise that all of the owner-managers in the metalworking firms were male with a median age in the 46-55 range. Overall, three-quarters were between 36 and 65 years of age and over two-thirds had had more than 5 years'

Table 1. Firm outputs

\begin{tabular}{|c|c|c|c|c|}
\hline & \multicolumn{2}{|c|}{ Metal products } & \multicolumn{2}{|c|}{ Metal treatments } \\
\hline & $n$ & $\overline{\text { Percentage }}$ & $n$ & Percentage \\
\hline Main output & 44 & 63 & 26 & 37 \\
\hline Examples & $\begin{array}{l}\text { Castings } \\
\text { Chisels } \\
\text { Chucks } \\
\text { Cutlery } \\
\text { Cutting tools } \\
\text { Fasteners } \\
\text { Forgings } \\
\text { Hand saws } \\
\text { Machine tools } \\
\text { Mixed fabrications } \\
\text { Scissors } \\
\text { Springs }\end{array}$ & & $\begin{array}{l}\text { Electroplating } \\
\text { Gold plating } \\
\text { Grinding } \\
\text { Heat treatment } \\
\text { Laser cutting } \\
\text { Powder coating } \\
\text { Shot blasting } \\
\text { Silver plating } \\
\text { Welding }\end{array}$ & \\
\hline
\end{tabular}

Source: Questionnaire survey. 
experience of running their own firm. Indeed, over a quarter had had experience of owning and/or managing another firm although not necessarily in the small firm sector. Although half had been employed in a small firm immediately prior to establishing their existing firm, a fifth had been employed in plants with over 500 employees, indicative perhaps of the employment contraction of these larger plants and an associated process of enterprise spin-off.

The owner-managers also had a long and significant association with the metal-working cluster in that nearly 9 out of every 10 were born and brought up in the city. The remarkable similarity of the residential and occupational histories of these individuals is indicative of a strong local industrial culture and many claimed to have been brought up in the metal-working tradition. Evocative of Marshall's industrial tradition 'hanging in the air' is the narrative of an owner-manager of a precision engineering shop

You heard it at home, you were brought up with it ... my granddad was a melter at Brown Bayleys and that was the only thing that you ever heard. That was the topic of conversation. His boss was Harry Brearley who invented stainless steel and, erm, and ... you know Harry Brearley used to come to our house, you know, when I was a kid, I mean I can actually remember the guy coming. You were brought up in that kind of atmosphere (precision engineer; interview).

In this kind of local environment, we might anticipate high levels of social interaction between owner-managers and their local suppliers. As was noted earlier, we focus here on each firm's principal supplier and the geographies of supplier links in order to determine the extent and significance of specifically localised forms of commodity exchange and any associated embodied transactions.

\section{Principal Suppliers and Embodied Trans- actions}

A firm's principal supplier was defined as the one providing the largest proportion by value of the firm's material inputs. This proportion varied from just under a tenth of annual material expenditure ( 9 per cent) to fourfifths (80 per cent). For the typical firm, the principal supplier accounted for one-third (the median value) of their annual materials spend. The main inputs are shown in Table 2. As can be seen, they were drawn predomi-

Table 2. Main material inputs

\begin{tabular}{llrr}
\hline Main input & Specific input & $n$ & Percentage \\
\hline \multirow{2}{*}{ Metals } & Stainless steel & 13 & 19 \\
& Mild steel & 11 & 16 \\
& Metal components (such as springs, blanks) & 8 & 12 \\
& Carbon steel & 7 & 10 \\
& Hi Speed steel & 6 & 9 \\
& Tool steel & 6 & 9 \\
& Unspecified steel & 6 & 9 \\
& Non-ferrous metals & 3 & 4 \\
& Castings/forgings & 2 & 3 \\
Sub-total & & 62 & 91 \\
Non-metal components & For example, plastic handles, ceramic valves & 6 & 9 \\
Consumables & For example, welding rods & 1 & 1 \\
Total & & $69^{\mathrm{a}}$ & 100 \\
\hline
\end{tabular}

${ }^{\mathrm{a}}$ One respondent did not answer this question.

Source: Questionnaire survey. 
nantly from other metals firms and of all supplies (not only those from principal suppliers) a mere 10 per cent came from other sectors including items such as plastic handles and ceramic valves. Most of the metal inputs consisted of billet, bar or rod steel with inputs dominated by stainless steel and mild steel. Only just over 10 per cent of the firms had more complex metal components (such as springs) as their main input.

A useful way of exploring the nature of inputs is to distinguish between routine or standardised 'off-the-shelf' inputs (which might require little of the personal contact associated with embodied transactions) and more complex inputs liable to require a higher frequency of embodied transactions between supplier and buyer. Overall, twothirds of the principal suppliers were supplying mainly 'off-the-shelf' inputs; the remainder supplied mainly specifically designed or modified inputs.

The pattern of deliveries associated with the main inputs was surprisingly varied. There appeared to be a clear distinction between half of the firms receiving deliveries weekly or more frequently and those whose deliveries were less than weekly (30 per cent) or followed an irregular pattern. In small firms, frequent deliveries might facilitate greater face-to-face transactions but equally the infrequent deliveries, especially those taking place on an irregular basis, might be precisely those that require intensive discussion and debate.

Buyer-supplier relations were rarely subject to formal contracts. Indeed, less than 20 per cent of the firms used a formal written contract additional to a basic written, and often faxed, order form. In part, this reflects the fact that owner-managers of small firms engaging on the whole in short production runs treat input requirements on an individual basis and order 'as required' in preference to establishing a formal supply contract.

The potential for interaction between the owner-manager and the supplier was eased by the fact that most of the contacts took the form of what Grabher (1993b) terms a 'dyadic' or two-person relationship. Personal contacts with the supplier firm were primarily (in three-quarters of the cases) with one main individual and, in the others, respondents had little difficulty in naming the person with whom they had dealt most frequently over the previous three months. The discussion that follows concerns the nature and extent of face-to-face transactions between the 'principal contact' at the supplier firm and the owner-managers of the 70 small Sheffield metal-working shops.

Perhaps the most striking characteristic of these relations is that over half of the ownermanagers had known their supplier contact for 5 years or more and, indeed, in 10 per cent of the cases this knowledge extended over at least two decades. A quarter of owner-managers had known their principal contact prior to establishing a trading relationship. A common example was one in which a supplier contact was known to the owner-manager prior to establishment of his own enterprise. Nevertheless, there appears to be a degree of turbulence in the system in that one-quarter of respondents had known their contact a year or less and half for under 5 years. Despite the length of time most owner-managers had known their contacts, few claimed to know their principal contact 'very well' (only 10 per cent thought that this was the case). However, the remaining responses were fairly evenly spread on a 4point scale from 'not well known at all' to 'known well'. Not surprisingly, Table 3 shows that the longer a supplier had known a contact the more likely it was that he knew him well $(\mathrm{p}<0.05)$.

As we have indicated, the recent literature has made much of embodied or face-to-face contact across firm boundaries as a means of developing trust relations, sharing information and generally integrating cluster activities. Overall, the 70 firms reported 765 meetings over the previous 12 months, a high figure reflecting the inclusion of 2 firms who met their suppliers more frequently than once a week. The median frequency of face-toface meetings was 3 times over the previous 12 months. Although some met more frequently, meeting more than once every 2 
Table 3. Personal knowledge of supplier contacts and time known

\begin{tabular}{lcc}
\hline & \multicolumn{2}{c}{ Length of time known } \\
\cline { 2 - 3 } How well known & Median and below & Above median \\
\hline One (not at all) & 11 & 1 \\
Two & 8 & 7 \\
Three & 10 & 8 \\
Four & 6 & 12 \\
Five (very well) & 0 & 7 \\
\hline
\end{tabular}

Notes: Kolmogorov-Smirnov $\max \mathrm{D}=0.37 ; \mathrm{p}<0.05 ; n=70$.

Source: Questionnaire survey.

weeks was rare. For a substantial minority of firms (almost one-fifth) there had been no face-to-face contact with the principal supplier in the previous 12 months. Despite this substantial minority, suppliers in the general case are neither remote nor unknown individuals on the end of a fax/telephone line; they are indeed individuals who are met with on a face-to-face basis.

We might anticipate that embodied transactions would be less necessary and thus less common where suppliers are already well known to the buyers, yet overall there was no significant relationship between the length of time a supplier had been known and the frequency of face-to-face meetings. However, Table 4 shows clearly that how well an owner-manager knew his supplier had a positive association with the frequency of embodied transactions $(\mathrm{p}<0.001)$. The direction of causality is unclear. Were owner-managers meeting frequently because they were well known to one another or had such familiarity arisen in the normal course of commodity exchange? High levels of embodied transactions were also associated with frequent deliveries of inputs $(p<0.05)$ and with those firms undertaking metal treatments and returning the treated metal to a customer (for example, electroplating) $(p<0.05)$. The link between frequent deliveries and embodied contact plausibly reflects a tendency among small firms for supplier contacts to make occasional deliveries themselves. More surprisingly perhaps, the frequency of embodied transactions in the case of suppliers of standardised inputs was al- most identical to that of suppliers of inputs with some element of customisation.

To this point, discussion has centred on the presence or absence of face-to-face transactions independent of their form or intent. As previously indicated, the interview schedule classified face-to-face interaction on the basis of where meetings took place and for what purpose. Although many of the linkages with suppliers involve embodied transactions, in the majority of cases the dealings were of a strictly business nature, taking place on business premises. Owner-managers very rarely met suppliers beyond a business context. Indeed, there were only 14 face-toface meetings undertaken in a social setting for social or recreational rather than business purposes. In such meetings, it was seen as 'bad form' to discuss business issues and social and economic aspects were rarely conflated:

On the golf course you talk about the girlfriend, the wife, the family, the last thing you talk about is business (electroplater; interview).

Business meetings on non-business premises were slightly more frequent (just under 10 per cent of all meetings). Some 60 such meetings were recorded, but they were of minor importance in the context of the overall number of face-to-face meetingsalthough, as one owner-manager observed,

You can talk business over a pie and pint as easy as over a desk (saw maker; interview). 
Table 4. Face-to-face meetings and personal knowledge of supplier contact

\begin{tabular}{lcc}
\hline & \multicolumn{2}{c}{ Face-to face meetings } \\
\cline { 2 - 3 } How well known & Median and below & Above median \\
\hline One (not at all) & 12 & 0 \\
Two & 12 & 3 \\
Three & 6 & 12 \\
Four & 7 & 11 \\
Five (very well) & 3 & 4 \\
\hline
\end{tabular}

Notes: Kolmogorov-Smirnov $\max \mathrm{D}=0.50 ; \mathrm{p}<0.001 ; n=70$.

Source: Questionnaire survey.

This appears to be very much the minority view and face-to-face meetings with suppliers rarely took place away from business premises.

We suggest that face-to-face meetings between owner-managers and their suppliers are essentially instrumental, business-focused and take place on the work premises of either the supplier or buyer. Just over 90 per cent of face-to-face meetings were of this type. One of the owner-managers captured succinctly the general theme

I don't encourage him (the most important supplier) to come and buy me a meal and a pint. I don't bother *** about; I just want to get down to business and get the job sorted out (precision engineer; interview).

Here, economic survival is the dominant logic of engagement. Socialising with suppliers is seen as having little or no further purpose. The aim of any meeting is to get the business done and owner-managers are focused on making things rather than making friends.

In sum, commodity exchanges between owner-managers and their suppliers are indeed accompanied by embodied transactions, albeit rather infrequently. Further, most of these transactions are of an instrumental economic nature. Nevertheless, there remains a possibility that commodity exchanges and embodied transactions may be more intense within a cluster. Perhaps proximity and embeddedness within a local social milieu pro- mote relatively more 'socialised' forms of exchange. It is to this issue that the paper now turns.

\section{Embodied Transactions: The Geographi- cal Dimension}

Geographical clusters tend to be premised on dense, localised interfirm linkages and thus associated with high levels of local sourcing. Amongst the sampled Sheffield metalworking firms, more than 50 per cent of firm expenditure on materials is retained within the locality (53 per cent) while over half of all the suppliers ( 52 per cent) are based in the local area. These figures are certainly high when compared, for example, with local sourcing levels of larger plants which are often as low as around 10 per cent even when the relevant scale is that of the region (Phelps, 1997; Crone and Watts, 2000). However, local sourcing levels are not markedly different from the figure of 63 per cent local sourcing found in a sample of foundries in the English Midlands in the late 1960s (Taylor and Wood, 1973). In short, there is little doubt that in the Sheffield metal-working cluster the small firms have ready access to a strong local supply base.

The local suppliers within the Sheffield metal-working cluster are predominantly other small and medium-sized enterprises and under a tenth of all local suppliers were estimated to be large (200 or more employees) local plants/firms. Sheffield and its 
immediate surrounding area have the hallmarks of a well-developed geographical cluster capable of providing an extensive range of material inputs to the metal-working sector. Although the location of the most important supplier shows a slightly lesser focus on the Sheffield region than the locations of all suppliers, two-fifths (40 per cent) of the principal suppliers were based locally. High levels of local sourcing offer considerable potential for embodied transactions between owner-managers and their suppliers.

It might be expected in turn that contacts with non-local suppliers would be rather more diffuse than their local equivalents. However, at both local and non-locally based supplier plants, three-quarters of Sheffield owner-managers have a single established contact to whom they direct enquiries. Developing a single named contact at the supplier is not, therefore, a distinct characteristic of within-cluster transactions. Similarly, there is no difference between local and nonlocal suppliers in the familiarity of the relevant contact and thus proximity to a supplier within the same cluster is not in itself sufficient to ensure a well-developed knowledge of supplier contacts.

Perhaps most striking of all the findings for the Sheffield firms is that, although embodied transactions with suppliers are evident, they are no more common in links with local suppliers than with those beyond the locality (Table 5). A high frequency of embodied transactions (those above the overall median contact level) is characteristic of between 40 and 50 per cent of the cases whether suppliers are located in the cluster or not-hence the difference is not statistically significant. There is little evidence here that proximity between parties intensifies the extent of face-to-face transaction between them (Sweeney, 1987). Even if the purely social meetings are excluded and the focus is solely on the strictly business, again there is no significant evidence of more frequent contact between owner-managers and their local suppliers.

It might well be anticipated that spatial proximity would also result in more extensive embodied transactions of a social as well as a strictly business nature. These social or recreational transactions are defined as either business meetings in a social setting or meetings that lack an explicit business rationale. In short, proximity may generate transactions that transcend an instrumental economic logic, producing 'friendships' as well as business associates. However, ownermanagers buying from a local principal supplier show no evidence of significantly more frequent embodied transactions of a social as opposed to a business nature. In fact, twothirds of both local and non-local plants have had no transactions of this form.

The lack of social mixing within the cluster might be seen to reflect simply the generally well-established nature of the material flows. To explore this possibility, ownermanagers were asked to consider whether

Table 5. Face-to-face contact and location

\begin{tabular}{lccr}
\hline & \multicolumn{3}{c}{ Face-to-face meetings } \\
\cline { 2 - 4 } Location of supplier & Median and below & Above median & Total \\
\hline Local & & & \\
$n$ & 15 & 13 & 28 \\
Percentage & 54 & 46 & 100 \\
Non-local & & & \\
$n$ & 25 & 17 & 42 \\
Percentage & 60 & 40 & 100 \\
\hline
\end{tabular}

Notes: Chi-squared $=3.38$ (not significant); $n=70$.

Source: Questionnaire survey. 
Table 6. Past 'social-only' contact and location

\begin{tabular}{lccc}
\hline & \multicolumn{3}{c}{ 'Social-only' contact } \\
\cline { 2 - 4 } Location & $\begin{array}{c}\text { Some social-only } \\
\text { contact in past }\end{array}$ & $\begin{array}{c}\text { Never had any } \\
\text { social-only contact }\end{array}$ & Total \\
\hline Local & 5 & 23 & \\
$n$ & 18 & 82 & 100 \\
Percentage & & & \\
Non-local & 17 & 25 & 42 \\
$n$ & 40 & 60 & 100 \\
Percentage & & & \\
\hline
\end{tabular}

Notes: Chi-squared $=7.29 ; \mathrm{p}<0.01 ; n=70$.

Source: Questionnaire survey.

they had ever had face-to-face contact with their supplier in a mainly social context. Overall, just under a third of ownermanagers had engaged in some form of social activity with their supplier at some point. But this relationship operates in precisely the opposite direction to that anticipated in the cluster literature, as shown in Table 6. Contact relating to non-business matters had occurred in two-fifths of the non-local cases, but in only one-fifth of corresponding local exchanges-a difference which proves statistically significant, albeit conversely to established insights $(\mathrm{p}<0.05)$. When buyers interact with suppliers at some distance from their home territory, they appear rather more likely to conflate business and social aspects of interfirm relationships.

The last two points bring into question the significance of spatial proximity in facilitating the development of embodied transactions within clusters. Indeed, in the case of the relationships between the Sheffield firms and their principal suppliers, geographical proximity bears little explanatory weight. Given a metal-working cluster with a rich and well-established tradition, the absence of a more intense or dense network of localised embodied transactions cannot simply be a function of the immaturity of the sector. Overall, it appears that the extent and frequency of embodied transactions are driven by a strong business or economic logic rather than muddied by the personal affinities or social connection between owner-managers and their associates. In this metal-working cluster at this point in time, owner-managers are no more engaged in face-to-face transactions within the cluster than without. Such a finding challenges the conventional wisdom concerning interfirm relationships within geographical clusters of industry. Some of the implications are discussed below.

\section{Discussion}

Convention suggests that clusters of small firms in related industries are expected to exhibit relatively dense patterns of social interaction, especially where clusters are limited in their geographical scope. Similarly, given studies of metal-working firms elsewhere, significant social linkages between firms would be anticipated in this particular case. However, in this cluster at this point in time, transactions of an embodied or face-toface form were decidedly limited-at least with reference to links with principal suppliers-and were no more extensive or significant than those with suppliers located beyond the cluster. The failure to find high levels of localised embodied transactions inevitably leads one to question the established view of the happy community of cosy collaborators seemingly typical of geographical clusters. Indeed, the absence of important embodied transactions between tightly clustered firms challenges the view that clusters 
derive important advantages from substantial face-to-face connections that bridge firms and provide the potential for learning, the construction of trust relations and the diffusion of best practice.

In questioning relatively well-established conventions, explanation of the patterns of commodity exchanges and embodied transactions exhibited by the Sheffield firms has been left open. Here, by way of conclusion, a number of suggestions are offered concerning the nature of this particular cluster and the associated transactional patternsalthough these suggestions may have a wider resonance.

First, it is suggested that more careful attention be paid to the purpose of embodied or face-to-face transactions. The existing literature suggests that local social interaction of this form is designed to develop and solidify social relations that foster understanding and trust between transacting parties. Yet embodied transactions are only one avenue by which knowledge about suppliers, their practices and their reputations is constructed. In the Sheffield case, where the cluster is mature and firms and personnel well-established, reputations are readily accessible. In short, the ready circulation of local knowledge obviates the need for direct access to original sources. Knowledge is 'out there' rather than in need of construction.

Secondly, this particular cluster may well be characterised by a somewhat insular and parochial local managerial culture. As independent entrepreneurs (albeit low-flying rather than high-flying in many cases) owner-managers in this small firm sector tended to pride themselves on their independence and autonomy. Indeed, most ownermanagers had little interest in belonging to any of the local institutions or collective organisations associated with the metal trades. These were commonly described as 'talking shops' from which few benefits were drawn and in which little was achieved. Two-thirds had no involvement with any local trade organisation and only four respondents thought that their degree of involvement in local economic institutions went beyond the norm. Similarly, the respondents appear to be poorly integrated into non-work organisations (such as sports clubs, charities and churches). Two-fifths reported no involvement at all and only a quarter self-reported above-average involvement in local non-work organisations.

In this sense, this may well be the wrong kind of cluster in which to anticipate intense social face-to-face interaction, especially that associated with a dynamic of growth, collective learning and innovation. This is a region in which employment in metal-working is falling, local labour markets are anything but tight and GDP has dipped below 75 per cent of the EU average enabling EU Objective 1 designation for the South Yorkshire region.

The focus of the study on material inputs and the characteristics of material inputs themselves might also be thought to militate against a high level of local embodied transactions. Linkages with customers, for example, might be seen to generate elevated levels of social interaction. Yet the decided absence of intense interaction with local suppliers suggests little scope for the transfer of tacit knowledge from the supplier to the Sheffield firm or for the development of closer partnerships within the supply chain. Turning to the material inputs themselves, as has been seen, most of the major inputs involved shipments of steel, a seemingly rather self-explanatory commodity requiring little discussion or negotiation between buyer and supplier. However, widely variable type, sizes and specifications of this basic commodity suggest a heterogeneous rather than homoneneous input market.

With these contextual matters in mind, it is necessary to be cautious about the wider significance of these findings. Indeed, this study focused on a dyadic link with one principal supplier and this link is likely to be better established than most-hence perhaps obviating the need for intensive interaction between owner-managers and suppliers. Instead, greater interaction during the search for suppliers might be anticipated (Watts et al., forthcoming) and in the early stages of affiliation. However, the evidence presented 
here suggests no significant relationship between link duration and the frequency of face-to-face contact. Greater instability, and hence greater interaction, might be expected in links with other suppliers (i.e. non-principal suppliers) playing a lesser role in the production process. Yet as a counter to that, the commitments of time inscribed in intensive social interaction are liable to generate diminishing returns for less significant suppliers.

The results presented in this paper examine only one aspect of clustering and clustering practices. Learning and innovation effects, for example, have been bracketed out, as well as utilisation of a common infrastructure and pool of labour skills. To question one dimension of clustering is clearly not to question them all. Yet while the arguments presented here are specific to a particular context of firms, place and time, little evidence was found to support the conventional view that traditional industrial clusters are characterised by dense and intensive face-to-face meetings between economic agents. To the extent that policy rests on conventional wisdom, the present authors would caution against the ready transfer of cluster models across contexts in favour of a much closer and more rigorous specification of the dimensions of clustering and their nature, significance and effects.

\section{References}

Amin, A. (2000) Industrial districts, in: E. ShEPPARD and T. J. BARnes (Eds) A Companion to Economic Geography, pp. 149-168. Oxford: Blackwell.

ApPlold, S. J. (1995) Agglomeration, interorganisational networks and competitive performance in the US metal-working sector, Economic Geography, 71, pp. 27-54.

BinfiEld, C. and HeY, D. (1997) Mesters to Masters: A History of the Company of Cutlers in Hallamshire. Oxford: Oxford University Press.

Boschma, R. and Lambooy, J. (1999) The prospects of an adjustment policy based on collective learning in old industrial regions, Geojournal, 49, pp. 391-399.

Camagni, R. P. (Ed.) (1991) Innovation Networks: Spatial Perspectives. London: Belhaven.
Camagni, R. P. (1995) Global network and local milieu: towards a theory of economic space, in: S. Conti, E. J. Malecki and P. Oinas (Eds) The Industrial Enterprise and its Environment: Spatial Perspectives, pp. 195-214. Aldershot: Avebury.

Crone, M. and WatTs, H. D. (2000) MNE supply linkages and the local SME sector: evidence from Yorkshire and Humberside, Local Economy, 15, pp. 325-337.

DEPARTMENT OF TRADE AND INDUSTRY (1999) Small and Medium Enterprise (SME) Statistics for the United Kingdom, 1998. URN 99/92. London: Government Statistical Service.

DEPARTMENT OF TRADE AND INDUSTRY (2001) Business clusters in the UK: A First Assessment. London: Department of Trade and Industry.

Garnsey, E. and LAwTON-Smith, H. (1998) Proximity and complexity in the emergence of high technology industry: the Oxbridge comparison, Geoforum, 29, pp. 433-450.

GAROLFINI, G. (1991) The Italian model of spatial development in the 1970s and 1980s, in: G. BENKO and M. DUNFORD (Eds) Industrial Change and Regional Development: The Transformation of New Industrial Spaces, pp. 85-114. London: Belhaven.

GERTLER, M. (1995) 'Being there': proximity, organization and culture in the adoption of advanced manufacturing technologies, Economic Geography, 71, pp. 1-26.

Gordon, I. R. and McCANN, P. (2000) Industrial clusters: complexes, agglomeration and/or social networks, Urban Studies, 37, pp. 513532.

GraBHER, G. (1993a) The weakness of strong ties: the lock in of regional development in the Ruhr area, in: G. GRABHER (Ed.) The Embedded Firm: On the Socio-economics of Industrial Networks, pp. 255-277. London: Routledge.

GrABHER, G. (1993b) Rediscovering the social in the economics of inter-firm relations, in: $G$. GRABHER (Ed.) The Embedded Firm: On the Socio-economics of Industrial Networks, pp. 131. London: Routledge.

GranOVETTER, M. (1985) Economic action and social structure: the problem of embeddedness, American Journal of Sociology, 91, pp. 481510.

Grotz, R. and Braun, B. (1993) Networks, milieux and individual firm strategies: empirical evidence of an innovative SME environment, Geografiska Annaler, 75B, pp. 149-162.

Hall, P. G. (1960) The location of the clothing trades in London, 1861-1951, Transactions of the Institute of British Geographers, 28, pp. 155-178.

HASSINK, R. (1997) What distinguishes 'good' 
from 'bad' industrial agglomerations, Erdkunde, 51, pp. 2-11.

HeRTOG, P. DEN ET AL. (Eds) (2001) Innovative Clusters: Drivers of National Innovation Systems. Paris: OECD.

Kaufmann, A. and Todtling, F. (2000) Systems of innovation in traditional industrial regions: the case of Styria in a comparative perspective, Regional Studies, 33, pp. 319-322.

KeEble, D. and WiLkinson, F. (1999) Collective learning and knowledge development in the evolution of regional clusters of high technology SMEs in Europe, Regional Studies, 33, pp. 295-303.

LORENZ, E. H. (1988) Neither friends nor strangers: informal networks of subcontracting in French industry, in: D. GAMBETTA (Ed.) Trust: Making and Breaking Co-operative Relations, pp. 194-210. Oxford: Basil Blackwell.

MacKinnon, D., Cumbers, A. and Chapman, K. (2002) Learning, innovation and regional development: a critical appraisal of recent debates, Progress in Human Geography, 26, pp. 293-311.

MARKUSEN, A. (1996) Sticky spaces in slippery space: a typology of industrial districts, Economic Geography, 72, pp. 293-313.

Marshall, A. (1919) Industry and Trade. London: Macmillan.

OAKEY, R., KiPLING, M. and Wildgust, S. (2001) Clustering among firms in the Non-Broadcast Visual Communications (NBVC) Sector, Regional Studies, 35, pp. 401-414.

PA CAMBridge ECONOMIC Consultants (1995) Assessment of the Wider Effects of Foreign Direct Investment in Manufacturing in the UK. London: Department of Trade and Industry.

PerRY, M. and GoldFInCH, S. (1996) Business networks outside an industrial district, Tijdschrift voor Economische en Sociale Geografie, 87, pp. 222-236.

Phelps, N. A. (1997) Multinationals and European Integration: Trade, Investment and Regional Development. London: Jessica Kingsley.

Pinch, S. and Henry, N. (1999) Paul Krugman's geographical economics, industrial clustering and the British motor sport industry, Regional Studies, 33, pp. 815-827.
Porter, M. E. (1998) Clusters and the new economics of competition, Harvard Business Review, November/December, pp. 77-90.

PORTER, M. (2000) Location, competition and economic development: local clusters in a global economy, Economic Development Quarterly, 14(1), pp. 15-35.

Pyke, F. and Sengenberger, W. (Eds) (1992) Industrial Districts and Local Economic Regeneration. Geneva: International Institute for Labour Studies.

Pyke, F., Becattini, G. and Sengenberger, W. (Eds) (1990) Industrial Districts and Inter-firm Co-operation in Italy. Geneva: International Institute for Labour Studies.

ScotT, A. J. (1988) Metropolis: From Division of Labor to Urban Form. Berkeley, CA: University of California Press.

Simmie, J., Sennett, J., Wood, P. and Hart, D. (2002) Innovation in Europe: knowledge and trade in five cities, Regional Studies, 36, pp. 47-64.

STABer, U. (2001) Spatial proximity and firm survival in a declining industrial district: the case of knitwear firms in Baden-Wurttemberg, Regional Studies, 35, pp. 329-341.

SweEneY, G. (1987) Innovation, Entrepreneurs and Regional Development. London: Pinter.

TAYLOR, M. J. and WOOD, P. A. (1973) Industrial linkage and local agglomerations in the West Midlands metal industries, Transactions of the Institute of British Geographers, 59, pp. 127154.

Tweedale, G. (1996) Steel City: Entrepreneurship, Strategy and Technology in Sheffield, 1743 to 1993. Oxford: Clarendon Press.

Watts, H. D., Wood, A. M. and Wardle, P. (forthcoming) Supplier search in industrial clusters: Sheffield metal-working in the 1990s, in: P. Oinas and A. LaJendiJK (Eds) Proximity, Distance and Diversity: Issues on Economic Interaction and Local Development. Aldershot: Ashgate.

Wise, M. J. (1949) On the evolution of the jewellery and gun quarters in Birmingham, Transactions of the Institute of British Geographers, 15, pp. 57-72. 